\title{
Racial Discrimination and Poverty Reduction for Sustainable Development
}

\author{
Umar Abdullahi Ahmed* \\ Department of Economics, Kaduna State University \\ Kaduna-Nigeria \\ Email: umed313@yahoo.com \\ Most. Asikha Aktar \\ Department of Economics, Comilla University \\ Cumilla, Bangladesh \\ Email: asikharita@gmail.com \\ Md. Mahmudul Alam \\ School of Economics, Finance and Banking \\ Universiti Utara Malaysia \\ Sintok, Kedah, Malaysia \\ Email: rony000@gmail.com \\ *Corresponding Author
}

\section{Citation Reference:}

Ahmed, U.A., Aktar M.A., \& Alam M.M. (2020). Racial Discrimination and Poverty Reduction for Sustainable Development. In: Walter Leal Filho et al. (eds), No Poverty: Encyclopedia of the UN Sustainable Development Goals. Springer, Cham. ISBN: 978-3-31969625-6. (online) https://doi.org/10.1007/978-3-319-69625-6_10-1

This is a pre-publication copy.

The published article is copyrighted by the publisher. 


\section{Racial Discrimination and Poverty Reduction for Sustainable Development}

\section{Definition}

The concept of racial discrimination is gaining a lot of recognition and acceptance in the drive to explain and reduce high levels of poverty among various social groups. Racial discrimination has many guises throughout the world as it affects individuals and communities. Racial discrimination can be seen as any form of unequal treatment against certain individuals or groups as a result of certain features attributed to such as skin color, ethnic origin or race (Felice 2002). In this case, individuals can experience discrimination such as denied employment opportunities, business engagements, being made a social or political outcast, and not having equitable access to available resources that other groups share. There is no doubt that discrimination based on race, gender or skin color at the individual level or within institutional formations promotes poverty and related situations (Hardaway and McLoyd 2009). This makes the challenge more important in order to help people escape from poverty. Accordingly, the issues discussed here will help researchers and policymakers end poverty in such a way that the strategies are sustainable.

\section{Introduction}

Sustainable development is an elusive concept with several definitions (Koglin 2009). It is also a concept that has recently captured the world's attention and 'imagination'. In conceptualizing sustainable development, Curren (2011) sees sustainable development as any "development that addresses the issues of the present without undermining the capacity of people in the future in addressing their own issues", or more expansively as, "any development that addresses the requirements and yearnings of the present without bartering the capacity to meet those yet to come". This conceptualization is based on the frequently used definition set out by the World Commission on Environment and Development in 1987, otherwise known as the Brundtland Commission (Sneddon et al. 2006). Sustainable development is commonly portrayed as integrating the economic, social and environmental spheres (Olawumi and Chan 2018). The mission to achieve sustainable development has been further advanced and offered in the United Nations" "17 Sustainable Development Goals" (SDGs), which are vital to attain the 2030 Sustainable Development Plan (UN 2015), that was accepted by global leaders in September 2015.

Hence, any situation that leads to treating a person or persons in a different way as a result of their racial, ethnic or cultural background can be regarded as racial discrimination (Small and Pager 2020). When such persons are denied access to the accepted basic needs of human prosperity and well-being, as a result of their race, color or nationality, this can result in poverty (Sieger 2011). This makes it all the more important to assess the relationship between sustainable development and "race and poverty". This entry looks at the possibility of eliminating "racial discrimination and poverty" in order to achieve sustainable development, firstly by discussing what "racial discrimination" is, and then it looks at some fundamental links between racial discrimination and poverty. Following this, the relationship between sustainable development and "race and poverty" is investigated. The final section of this entry focuses on policy suggestions and recommendations.

\section{Definition of Racial Discrimination}


Before defining racial discrimination, it is necessary to clarify precisely what race entails. In this regard many views see race as a "natural" classification that reflects significant biological variations among certain sets of people who have different ancestral origins from different parts of the globe. Since racial groupings can generally be linked to observable physical variations between groups of people, the apparent genuineness of race is self-evident to most people (Rzepnikowska 2019). Such a concept reflects an essential misunderstanding regarding the nature of racial categorizations. Race can become a social class and may not simply remain a biological one. Although racial classifications commonly employ inherited biological qualities as principles for classification, nonetheless, the manner in which such traits are accepted and are converted into the categories is what we refer to as "races", which can be defined basically by social conventions and not by biology (Roth 2016).

According to one definition, "racial discrimination" refers to unequal dealings with persons or groups based on their racial affiliation or ethnicity (Pager and Shepherd 2008). In trying to define racial discrimination, various scholars and legal professionals distinguish between two categories of description as differential handling and unequal impact (Reskin et al. 1999; Blank et al. 2004). Differential handling arises when individuals receive unequal treatment based on their race, while unequal impact occurs when individuals are treated similarly in accordance to given legal "conventional rules and procedures". However, when the latter is implemented in ways that tend to favor some members of one group against another, then this leads to differential handling. Therefore, racism or racial discrimination tendencies refer to the outcome of the dynamic interactions in a given societal context where race-based assumptions are made, and lead to labeling and discrimination (Pager and Shepherd 2008). Racism can exist in social activities, practices, or political structures (e.g. South Africa's apartheid system) that help in promoting prejudice through discrimination. The principle ideology surrounding racial discrimination practices normally comprises the ability to subdivide individuals into some distinct sets which are characterized by a sense of 'inferior' and 'superior' classes (GolashBoza 2016).

Racial discrimination can manifest itself in various facets and related activities of social, political and economic life. These activities may comprise of xenophobic actions, otherness, exclusion, unnecessary positioning in ranking, supremacism, and other socially abnormal situations (Bailliet 2018). Racial inclination and ethnicity are seen as acts of isolation in the social sciences. Such terms have a long historical tradition of being used in the mainstream social sciences. Moreover, racial discrimination is regularly associated with the abuse of human rights that is normalized through the generations and becomes evident in cultural tenets and practices, institutional as well nationwide standards and practices. It is also associated with daily behavioral features of individuals and other groups with certain societies (Essed 1991; Jones 1997; Dovidio et al. 2005). Moreover, it is an important element that encourages the aggravation of poverty as defined by the United Nations (2013), i.e. "a human condition branded by continuous or chronic deprivation of basic resources, competences, choices, basic security and ability necessary for the enjoyment of an adequate requirement and standard of living which includes other civil, traditional, economic and socio-political rights".

\section{Dimensions of Racial Discrimination}

The existence of racism is believed to be a global one. It exists in offices, factories and many other work places, healthcare and the legal system (United Nations 2005). In the following subsections the issue of racial discrimination will be discussed in five contexts: employment, 
housing, migration, health and administration of justice. This argument seeks to re-acquaint readers with some of the key dimensions relating to racial discrimination.

Racial discrimination and employment

Racial discrimination in employment can be direct or otherwise (United Nations 2005). Direct discrimination in employment situations happens when an employer denies opportunity for an individual to work due to a person's race, color of skin or other reason. Thus, discrimination can be direct as well indirect when institutional strategies or practices effectively bar individuals from specific groups to enjoy access to equal job or workplace promotion opportunities.

Racial discrimination in the employment sphere is not only associated with rich economies. It exists in many poor nations where influential local groups mostly with the complicity of certain political parties and their government agencies, subordinate individuals from other groups (Pager and Shepherd 2008). In spite of the fact that there have been some amazing gains in the working class position of racial minorities, large disparities persist. For example, in the United States, African-Americans are twice as likely to be jobless than whites and earn half the wages: blacks and Hispanics' wages kept on falling behind those of whites (Pager and Shepherd 2008). Long range research has analyzed how much role discrimination plays a part in molding the contemporary labor market characteristics. Experimental studies that examine recruiting processes in audit firms have convincingly discovered strong proof of racial discrimination, through evaluations of white inclination ranging from around 50\% to 240\% (Cross et al. 1989; Turner et al. 1991; Fix and Struyk 1993; Bendick et al. 1994; Pager 2007).

\section{Racial discrimination and health}

The Durban World Conference (2001) accepted and recommended actions given the evidence of numerous nations where their healthcare systems disadvantaged persons from certain ethnic and racial backgrounds, including immigrants and expatriates. Numerous factors associated with the point of social can restrain or facilitate access of various ethnic groups to healthcare services. They may include income level, training, age, language abilities, gender and their own opinions regarding healthcare provision (UN 2001).

\section{Racial discrimination and housing}

Residential discrimination based on race remains a prominent feature of city life in the modern United States. In this context, African-Americans were separated from whites especially during the 1990s as they simply experienced what had happened since the early 20th century if not earlier, and such levels of discrimination still continue despite rising socio-economic wealth (Massey and Denton 1993). Despite some reductions in the rate of discrimination especially during the 1980s to the early 2000s, some individuals especially blacks and other minority groups are still experiencing forms of residential discrimination (Logan et al. 2004). In trying to expose the discrimination problems in the housing segment, experimental research utilizing audit data was conducted. Based on this, assessments were carried out by a department in charge of Housing and Urban Development between 2000 and 2002, the objective being to report any form of housing discrimination against people who are blacks, Asians, American 
natives and Latinos as well. The research employed around 5500 paired tests in nearly 30 municipal areas (Turner and Ross 2003; Roy et al. 1992; Turner et al. 2002; Feins and Bratt 1983). The findings confirm the existence of bias in several dimensions in which blacks face continuously experience prejudiced treatment.

\section{Racial discrimination and migration}

The rising ethnic and racial differences and tensions within some societies to some extent reflect the migration or refugee situation in many parts or the world (Pager and Shepherd 2008). Uncontrolled or hard-to-manage migration is leading to more nation-states becoming increasingly multi-ethnic, which means they have to confront the rising challenges of housing or hosting various peoples from diverse cultural backgrounds, races, different religious beliefs, language affiliations, etc. (Erel et al. 2016). In order to address the realities of rising diversity, it means putting economic, political, legal and social structures in place, in order to generate mutual respect and good relations between ethnic and/or racial groups. Nonetheless, racial discrimination remains strong in many societies that have received large numbers of immigrants such as workers or asylum-seekers.

Racial discrimination and the administration of justice

It is a disturbing fact as discrimination persists in the administration of justice and legal procedures. Furthermore it has been indicated by experts, such as NGOs, that such racial and ethnic discrimination tends to be normalized and habitual in national structures of criminal justice, no matter what type of legal system is in place (Weitzer 1996).

\section{The fundamental link between racial discrimination and poverty}

There is a clear correlation between racial discrimination and poverty which is undeniable, and the connections are confirmed by both statistics and life experiences. The following statistics (see Table 1) shows that in New Jersey, color populations and especially African-Americans and Hispanics have far smaller incomes than those classified as white non-Hispanic. It should be noted that racism operates along a complicated and wide spectrum. The spectrum involves deliberate, overt discrimination and varying degrees of preferential treatment but access to power and opportunity are the more fundamental characteristics. Racism occurs when different racial or ethnic groups have unequal levels of access to power, authority and resources and these are built into the political system (Bailey et al. 2017). This structural racism leads to unequal access to opportunities ingrained in society which has profoundly negative implications, and is the primary cause of poverty (APN 2017).

Table 1: Poverty Rate by race and age in New Jersey, USA

\begin{tabular}{|l|l|l|l|}
\hline & White Non-Hispanic & African-American & Hispanic \\
\hline All ages & $6.3 \%$ & $18.6 \%$ & $20.2 \%$ \\
\hline
\end{tabular}




\begin{tabular}{|l|l|l|l|}
\hline Under 18 & $8.1 \%$ & $26.9 \%$ & $27.6 \%$ \\
\hline $18-64$ & $6.1 \%$ & $16.5 \%$ & $16.8 \%$ \\
\hline $65+$ & $5.3 \%$ & $13.3 \%$ & $20.4 \%$ \\
\hline
\end{tabular}

Source: US Census Bureau, American Community Survey 2015

For instance, many Americans who want to see poverty reduced in their country assert that race is no longer important for fashioning solutions. Both compassion and pragmatism often reflect this view. As stated by Pager and Shepherd (2008) when opportunities are not fair, when life chances are skewed, when one's skin color makes it three or four times more likely to experience poverty - racism is at stake. Persistent poverty and various related social dynamics are skewed along racial and ethnic lines. It has also been noted that the issue of poverty cannot be solved unless the complex and ongoing relationship between poverty and race is acknowledged and addressed (Posel 2010). Accordingly, racial discrimination and poverty are so interconnected and separating the two may be seen as impossible.

Furthermore, history shows that poverty reductions do not consistently remove racial disparities nor do they necessarily help people of color on low incomes (Jenkins 2007). For example, the poverty rate for African-Americans and Latinos taken together in 2000, after a decade of unprecedented economic growth, was still 2.6 times greater than that for white Americans. This gap has been startling but in more than three decades it has recorded the lowest discrepancy in poverty rates between whites and others. From 2001 to 2003, when the US economy in the wake of 9/11 contracted, the poverty level rose more sharply for most colored populations than for whites, widening the gap in racial poverty. Around 2004 and 2005, although the total number of poor Americans declined by approximately 1 million to 37 million, the levels of poverty significantly increased for most color groups (Jenkins 2007). It is evident that poverty reduction may not necessarily reduce racial discrimination nor put all ethnic groups on an equal footing. Yet without addressing race-based obstacles relative to opportunity, we cannot expect to tackle poverty in a substantive or permanent way. Racial discrimination can both cause poverty and be a hurdle in eliminating poverty (APN 2017). This problem of racial discrimination therefore should be taken up together with vision one of the Sustainable Development (SDG1) program. That is, eradicating extreme poverty by 2030 through successful elimination of all forms of racial discrimination.

\section{"Race and Poverty" in the context of sustainable development}

As the globe and economic agents continue to evolve, some fundamental understanding and activities relating to development today are expected to occur not at the expense of what the future holds for tomorrow. The term 'sustainable development' is a now well-utilized one and continues to gain high level of popularity within and beyond academia especially in the more developed regions of the globe. Sustainable development entails a situation of satisfying the required needs of the present generation without undermining the capacities of future generations to meet their needs (United Nations General Assembly 1987). Hence, sustainable development is simply, development that fulfills some norms of sustainability or similarity with a practically identical or better standard of living in the future. The cardinal objective of 
development is to enhance the quality standard of life, while the vital objective of sustainability is to operate within the natural environment's capacity. Thus, as sound and effective sustainable development is determined to eradicate poverty especially given the rise in recent decades of lethal ecological hazards, there are substantial changes that will affect what the goals are for the 'Global North' member countries, as well as those of 'Global South' (Willis 2016).

From a global perspective, the cardinal strategies to tackle current and future sustainability issues, were approved and adopted by all the United Nations member countries is 2015. In this, a document titled "Transforming our World: the 2030 Agenda for Sustainable Development" was agreed upon. This allows advocate nations to display their intention to create sound links between "social, economic and environmental" aspects of life which are considered to be the three key stages of sustainable development (UN 2015).

On $17^{\text {th }}$ February 2015, H.E. Ambassador E. Courtenay Rattray, who is the Permanent Representative of Jamaica declared that "Our collective vision for the world in 2030 must be one wherein we have made significant progress (to achieve the SDGs) through the removal of all structural and systemic impediments to (their) fulfillment" (Okorodudu 2015). He also stated "that racism and racial or ethnic discrimination will continue to function as structural and systemic barriers to sustainable development if they are not addressed" (Thakker 2018). It has been established that SDG 1 can only be adequately achieved when issues relating to the effects of racial discrimination are addressed. This is a result of the connection and relationship between the two issues. Conversely, the major objective of sustainable development is eradicating poverty in all its forms and dimensions by 2030, and this means there is an urgent need to tackle the problems of racial discrimination as well. The persistence of racial discrimination will no doubt continue to undermine the fundamental provisions of liberty, economic opportunity and fairness for all.

During the year 2015, it was reported that about 735 million people were still living on less than $\$ 1.90$ per day; where many people lack adequate food, clean drinking water and decent sanitation, as stated by UNDP (2015). Meanwhile, fast growth in a few countries like China and India has helped move millions of people out of poverty, but such progress remains uneven due to racial or ethnic discrimination. A similar trend is observed in many other regions of the globe, such as parts of South Asia and sub-Saharan Africa (SSA). Such regions account for about $80 \%$ of all people living in conditions of extreme poverty (UNDP 2015). Consequently, the importance of abolishing racial discrimination in order to eradicate poverty cannot be over emphasized. Many countries have socio-economic and political systems that encourage or foment great differences between groups of people based on racial, color, ethnic, lineage and cultural characteristics. Any efforts to prohibit and eliminate any causal factors that lead to discrimination play a vital role in poverty eradication. Nonetheless, given that poverty eradication and creating prosperity in a changing global space varies from one economy to another, it is of great importance to include issues related to racial discrimination and address them in a positive way so that solutions are developed and implemented.

\section{Eradicating racial discrimination and poverty to achieve sustainable development}

It was in 2016 that the 17 SDG goals of the 2030 Agenda towards Sustainable Development became official. These goals were adopted by world leaders in September 2015. With this agenda, countries will put into action all the necessary efforts to end any forms of poverty, 
combat inequality issues and tackle all types of discrimination (UN 2015). With the advent of environmental justice which emerged in communities of color and less privileged communities, this has posed certain challenges to the idea of non-political environmentalism, leading to controversies about environmental racism, discrimination and classism issues. One may not need be compelled to search far or deep in order to discover information showing that poor individuals and people of color, residing in urban and rural communities alike, face serious consequences of environmental contamination and degradation (Jones and Rainey 2006). They have not really benefited from any of the environmental victories like establishing wilderness zones, supply of clean and uncontaminated water or having less exposure to toxic elements, etc. (Roberts et al. 2018).

Despite certain improvements in recent years to end racial discrimination (both known and unknown), it remains a source of universal crisis and very evident marginalization of many individuals and groups all over the world. These levels of imbalance cause disproportional poverty situations and restrict access to authority, equity, educational facilities, employment and medical services. Accordingly, there is increasing concern about what the post-2015 SDGs can achieve and especially the likely causes and consequences of racism and racial discrimination. Consequently, in order to make good progress towards attaining sustainable development that also functions to reduce poverty, the causes and sources of racial discrimination must be addressed.

According to the recent World Bank (2020) estimates, around 40 to 60 million people are likely to be affected by extreme poverty and the numbers are rising. Realistically, people are living on less than $\$ 1.90 /$ day in 2020, not helped by the COVID-19 pandemic, which has worsened the situation of 2019. The global poverty figures are likely to increase by around $0.3 \%$ to $0.7 \%$ leading to $8 \%$ poverty worldwide in 2020 . Provision of social protection arrangements can to some extent remove the effects or conditions of poverty. Such arrangements may, however, lead to trade-offs or compromises in various socio-economic and environmental objectives, meaning that achieving sustainable development is negated. Nevertheless, there is a pressing need for the global community to show more concern to address the dynamics and related issues surrounding the politics of racial discrimination, such as rising human rights violations or genocides that simply increase poverty globally. What remains clear is the fact that, in spite of evidence clearly showing that racial discrimination exists in many social structures, more efforts will be required to address the concealed and unreported cases of discrimination.

Reducing poverty remains one of the greatest international challenges confronting the human race and is part of the sustainable development process. Addressing racial discrimination will also mean fast-tracking sustainable development. It means that separating poverty eradication and sustainable development is not possible.

\section{Policy Suggestions}

The prohibition of racial discrimination remains a key issue internationally for poverty reduction. Imposing responsibilities on member states and ensuring their implementation with respect to removal of discrimination within public and private spheres is now very important. The World Conference on Racism, Racial Discrimination, Xenophobia and related issues, otherwise known as the Durban Declaration and Plan of Action of 2001, produced the most credible and detailed plan to address this scourge. Despite the efforts made to turn such 
fundamental human rights requirements into practice, racial discrimination still persists in various forms. As such racial crime, hate speech and stereotyping are features of daily life in many parts of the world. Many communities remain overwhelmingly marginalized, with significant minorities being silenced or negated. Racial discrimination continues to make the sustainable development goals unachievable and undermines the basic rights of millions of people. No state is free from racial discrimination and it is something that they must eradicate.

Combating racism demands a holistic approach, courageous strategies and policies that can tackle the various types of racial discrimination. Subsequently to addressing the issue of racial discrimination, the Durban Review Conference held in 2009 at Geneva, the Elimination of Racial Discrimination Committee and the Council of Human Rights, recommended the implementation of effective national action plans against racial discrimination. At a national level also, action plans need to be put in place and recognize the historical and legal conditions necessary. It is binding upon each member state to carefully agree upon what policy measures, plans and actions are required to achieve non-racial discrimination. Regardless of their differences, all action plans at the national level should put great emphasis on the following matters:

\section{Adopting laws and policies}

An important first step in prohibiting racial discrimination in the context of eradicating poverty is the adoption of rights-based laws and policies. Beyond the adoption of rights-based laws and policies, it is important to implement such policies, otherwise deeply rooted structural racial discrimination will not be eradicated.

An inclusive quality education for all

Education remains one of the most powerful and established tools for sustainable development. It is an important mechanism through which socio-economically marginalized people can be assisted to lift themselves out of poverty. It plays a cardinal role in women's empowerment, protection of children from any form of exploitation, upholding human rights provisions and freedom. It can also go a long way to ensure the protection of the environment, promotion of human tolerance and respect between people. It is also important for states to recognize the persistence of structural forms of racism and various forms of discrimination within the educational system. Hence, they must ensure that people have good access to quality and affordable education so that all graduates can compete equally with others in the labor market.

\section{On-the-Job training programs}

On-the-job training programs should support low-income people to operate in a globalized economy. With the combination of anti-discrimination enforcement that warrants equal access to such opportunities and programs, people can access the jobs of their choice. Similarly, strengthening the freedom to organize training programs is important to help low-wage workers get out of poverty. However, this must be done in collaboration with civil rights-type organizations in order to root out any form of racial exclusion that may occur in unions or cooperatives. This means combining an all-inclusive immigration restructuring that offers new- 
comers an avenue to easily obtain citizenship permits, earn a living wage and have industrial protections that can reduce and discourage racial discrimination.

(iv) Protecting against discrimination and promoting equality

The eradication of organizational racism remains a key initiative for attaining the SDGs. This is further highlighted in the Durban Declaration and Programme of Action, which states that:

"Poverty of any form, underdevelopment, unacceptable marginalization, social rejection and economic inequalities are closely associated with acts of racism, racial discrimination, xenophobic tendencies and related intolerances that can contribute to the persistence of racial behaviours and practices which in turn leads to more poverty" (Alvez 2003).

States should take the necessary actions which may include halting all policies or practices that reflect racial discrimination and thereby worsen the poverty situation.

\section{(v) "Opportunity impact statement"}

Strong and promising approaches should be employed by requiring an "opportunity impact statement" when public resources are to be expended on development projects. Such a statement would provide some credible explanation, for example, as to whether a newly constructed highway will connect areas of low-income to good jobs and educational institutions rather than serving only affluent communities and their interests. Such a statement would provide details of where and how available job opportunities will arise. Different communities would take the responsibilities and manage the burden of environmental outcomes and other possible outcomes (rather than just working on a project that replicates traditional forms of inequality). It would serve as a measurement for not only the project's success but also reduction in the poverty level where more opportunities are offered to all people.

(vi) Build effective, accountable and inclusive institutions at all levels

In order to advance the SDGs, nation-states must put in place and support effective, accountable and all-inclusive public sector establishments that protect all peoples' human rights. Organizations such as nationwide human rights organizations, labor associations, national mechanisms for the progress of women, and that of persons with special needs should also be empowered with monitoring powers.

\section{(vii) Promoting special measures and actions}

In some cases, special measures and actions may be required in order to help disadvantaged individuals and groups towards poverty eradication, by removing the link between poverty and any form of racism, especially where such discrimination is embedded and structural. This can only be done through effective and enforced laws, sound policies and practices that help to secure the complete and equal enjoyment of rights and privileges by all people in society. The proposed measures might emerge in the form of executive provisions, administrative directives, 
budgetary and regulatory mechanisms as well as all other programs and special regimes that will favor any disadvantaged groups.

Furthermore, other policy recommendations that promote the required support for those at risk of being neglected due to racism include:

- To strongly declare that "equal societies will grow more equally".

- To eliminate any form of racial discrimination and poverty creation situations so that the stipulated 2030 Agenda can be achieved realistically and effectively, with a particular view on reaching those "furthest behind first".

- To reiterate the important roles that states must provide in the form of protective frameworks in order to eliminate any racial discrimination within society. This may include the use of special actions even on a temporary basis specifically for those who are seen to suffer from any form of racial discrimination.

- To support the introduction of appropriate monitoring frameworks and institutions throughout the nation's infrastructure; this may include national human rights bodies, labor organizations, employer bodies, the bureaucracy, etc., to ensure that women are advanced economically, politically and socially.

- To strengthen existing data collection methods and monitoring measures so that any racial discrimination or inequality situations are detected and then acted on.

\section{Conclusions}

As racism remains a global reality, especially during the last few decades despite the enormous advances made economically, a vital approach to its reduction is to recognize the role of sustainable development. Making the link between racial discrimination and poverty, any racial discrimination tendencies or actions must be acknowledged as a serious problem and such must be removed if sustainable and equitable economic development is to be attained. Hence, policymakers must ensure that this global calamity, which originated centuries ago in a series of historic injustices, is resolved through government strategies. Furthermore, they should also ensure that the implementation of racial discrimination laws and policies leads to no bias.

Thinking of race and poverty within such terms that are related to share values or by linking the fortunes of all the people, the societal approaches to politics and policies will begin to be different._Rather than balancing the lists of communities and recognized groups, we may be left with simply moving forward all together as a varied but cohesive community that addresses any rising issue through unity of such forces that once in history tend to divided us.

\section{Synonyms}

Discrimination; Segregation; Racism; Discrepancy; Inequality; Eradication

\section{Cross-References}

Inequality and Poverty: Challenges to Sustainability

$>$ Social Justice and Sustainability

$>$ Race Discrimination: Evolution and Economic Impact 
$>$ Prejudice against poor and vulnerable

\section{References}

Alvez JA (2003) The Durban conference against racism and everyone's responsibilities. University of San Francisco Law Review, 37(4), p.4. Available at: https://repository.usfca.edu/cgi/viewcontent.cgi?article=1268\&context=usflawreview [Accessed on 11 September, 2020].

APN (2017). The uncomfortable truth: racism, injustice, and poverty in New Jersey: A call for action. Available

at: http://www.antipovertynetwork.org/resources/Documents/The\%20Uncomfortable\%20T ruth\%20Final\%20-\%20web.pdf

Bailey ZD, Krieger N, Agénor M, Graves J, Linos N, Bassett MT (2017) Structural racism and health inequities in the USA: evidence and interventions. The Lancet, 389(10077), pp.1453-1463. https://doi.org/10.1016/S0140-6736(17)30569-X

Bailliet, Cecilia M (2018) Protection of refugees, returnees, migrants, and internally displaced persons against racism, xenophobia, and discriminatory practices. Available at SSRN: https://ssrn.com/abstract=3481195 or http://dx.doi.org/10.2139/ssrn.3481195 [Accessed on July 5, 2018].

Bendick M, Jackson C, Reinoso V (1994) Measuring employment discrimination through controlled experiments. Rev. Black Polit. Econ. 1994; 23:25-48.

Blank RM, Dabady M, Citro CF (2004) Measuring Racial Discrimination. Panel on Methods for Assessing Discrimination, on behalf of the National Research Council.

Corann Okorodudu (2015) Integrating the Elimination of Inequalities due to Racism into the Framework of the UN Post-2015 Sustainable Development Agenda: 1 Recommendations from Civil Society.

Cross H, Kenney G, Mell J, Zimmerman W (1989) Differential Treatment of Hispanic and Anglo Job Seekers: Hiring Practices in Two Cities. Washington, DC: Urban Inst.

Curren R (2011) Sustainable Development. In: Chatterjee D.K. (eds) Encyclopedia of Global Justice. Springer, Dordrecht. Available at: https://doi.org/10.1007/978-1-4020-91605 396 [Accessed on 18 August 2020].

Dovidio J F, Glick PG, Rudman L (2005) On the nature of prejudice: Fifty years after Allport. Malden, MA: Blackwell.

Erel U, Murji K, Nahaboo Z (2016) Understanding the contemporary race-migration nexus. Ethnic and Racial Studies, 39(8), pp.1339-1360.

Essed P (1991) Understanding everyday racism: An interdisciplinary theory (Vol. 2). Sage.

Feins JD, Bratt RG (1983) Barred in Boston: racial discrimination in housing. J. Am. Plann. Assoc. 49:347-357.

Felice WF (2002) The UN Committee on the Elimination of All Forms of Racial Discrimination: Race, and economic and social human rights. Hum. Rts. Q., 24, p. 205.

Fix M, Struyk RJ (1993) Clear and Convincing Evidence: Measurement of Discrimination in America. Washington, DC: Urban Inst.

Golash-Boza T (2016) A critical and comprehensive sociological theory of race and racism. Sociology of Race and Ethnicity, 2(2), pp.129-141. doi.org/10.1177/2332649216632242

Hakken J (1979) Discrimination against Chicanos in the Dallas Rental Housing Market: An Experimental Extension of the HMPS. Washington, DC: US Dep. HUD.

Hardaway CR, McLoyd VC (2009) Escaping poverty and securing middle class status: How race and socioeconomic status shape mobility prospects for African Americans during the transition to adulthood. Journal of youth and adolescence, 38(2), p.242. 
https://www.worldbank.org/en/topic/poverty/overview [Accessed on 18 August 2020].

Jenkins A (2007) Inequality, Race and Remedy. Available at: https://prospect.org/specialreport/inequality-race-remedy/ [Accessed on 18 August 2020].

Jones JM (1997) Prejudice and racism. New York: McGraw Hill.

Jones RE, Rainey SA (2006) Examining linkages between race, environmental concern, health, and justice in a highly polluted community of color. Journal of Black Studies, 36(4), pp.473-496. doi.org/10.1177/0021934705280411

Koglin T (2009) Sustainable development in general and urban context: a literature review. Department of Technology and Society, Lund University.

Leisinger KM (1995) "Sustainable Development: A Common Challenge for North and South". International Journal of Sociology and Social Policy, Vol. 15 No. 8/9/10, pp. 27 64. https://doi.org/10.1108/eb013222

Logan JR., Stults BJ, Farley R (2004). Segregation of minorities in the metropolis: Two decades of change. Demography, 41(1), 1-22.

Massey DS, Denton NA (1993) American Apartheid: Segregation and the Making of the Underclass. Cambridge, MA: Harvard Univ. Press.

Northwest Cameroon: Reconnoitering the challenges and potential of community-based

Olawumi TO, Chan DW (2018) A scientometric review of global research on sustainability and sustainable development. Journal of cleaner production, 183, 231-250.

Pager D (2007) the use of field experiments for studies of employment discrimination: contributions, critiques, and directions for the future. Ann. Am. Acad. Polit. Soc. Sci. 609:104-133.

Pager D, Shepherd H (2008). The Sociology of Discrimination: Racial Discrimination in Employment, Housing, Credit, and Consumer Markets. Annual review of sociology, 34, 181-209. Available at: https://doi.org/10.1146/annurev.soc.33.040406.131740

Posel D (2010) Races to consume: revisiting South Africa's history of race, consumption and the struggle for freedom. Ethnic and Racial Studies, 33(2), pp.157-175.

Reskin BF, McBrier DB, Kmec JA (1999) the determinants and consequences of workplace sex and race composition. Annual review of sociology, 25(1), 335-361.

Roth WD (2016) The multiple dimensions of race. Ethnic and Racial Studies, 39(8), pp.13101338. DOI: $10.1080 / 01419870.2016 .1140793$.

Roychoudhury C, Goodman AC (1992) An ordered probit model for estimating racial discrimination through Fair Housing audits. J. Hous. Econ.2:358-373.

Roychoudhury C, Goodman AC (1996) Evidence of racial discrimination in different dimensions of owner-occupied housing search. Real Estate Econ. 24:161-178.

Rzepnikowska A (2019) Racism and xenophobia experienced by Polish migrants in the UK before and after Brexit vote. Journal of Ethnic and Migration Studies, 45(1), pp.61-77.

Sieger LE (2011) Poverty In: Chatterjee D.K. (eds) Encyclopedia of Global Justice. Springer, Dordrecht. Available at: https://doi.org/10.1007/978-1-4020-9160-5_360

Small ML, Pager D (2020) Sociological perspectives on racial discrimination. Journal of Economic Perspectives, 34(2), pp.49-67.

Sneddon C, Howarth RB, Norgaard RB (2006) Sustainable development in a post-Brundtland world. Ecological economics, 57(2), pp.253-268.

Tantoh HB, Simatele D (2018) Complexity and uncertainty in water resource governance in

Thakker AY (2018) India at the United Nations: An Analysis of Indian Multilateral. Available at:

https://www.orfonline.org/wpcontent/uploads/2018/03/ORF_Occasional_Paper_148_In dia-UN.pdf [Accessed on 09 September, 2020]

The Amnesty International report (2001) Racism and the Administration of Justice (AI Index: ACT 40/020/2001). Amnesty International Publications, United Kingdom. 
Timmons Roberts J, Pellow D, Mohai P (2018) Environmental Justice. In: Boström M., Davidson D. (eds) Environment and Society. Palgrave Studies in Environmental Sociology and Policy. Palgrave Macmillan, Cham. https://doi.org/10.1007/978-3-31976415-3_11.

Turner M, Fix M, Struyk R (1991) Opportunities Denied, Opportunities Diminished: Racial Discrimination in Hiring. Washington, DC: Urban Inst. Press.

Turner MA, Ross SL (2003) Discrimination in Metropolitan Housing Markets: National Results from Phase 2-Asians and Pacific Islanders. Washington, DC: Dep. Hous. Urban Development. Available at: http://www.huduser.org/publications/pdf/phase2_final.pdf [Accessed on 18 August 2020].

Turner MA, Ross SL, Gaister GC, Yinger J (2002) Discrimination in Metropolitan Housing Markets: National Results from Phase 1 HDS 2000. Washington, DC: Urban Inst., Dep. Hous. Urban Development. Available at:http://www.huduser.org/intercept.asp?loc=/Publications/pdf/Phase1_Report.pdf [Accessed on 18 August 2020]

UN (2001) Report of the world conference against racism, racial discrimination, xenophobia and related intolerance. Available at: https://www.un.org/WCAR/durban.pdf [Accessed on 28 August 2020]

UNDP (2015). Available at: https://www.undp.org/content/undp/en/home/sustainabledevelopment-goals/goal-1-no-poverty.html [Accessed on 18 August 2020]

United Nations (2005) Dimensions of racism. Proceedings of a Workshop to commemorate the end of the United Nations third decade to combat racism and racial discrimination Paris, 19-20 February 2003. New York, Geneva.

United Nations (2013) Online survey on "Promoting empowerment of people in achieving poverty eradication, social integration and full employment integration and full employment and decent work for all". Available at: https://www.un.org/esa/socdev/publications/FullSurveyEmpowerment.pdf

United Nations General Assembly (2015) Resolution adopted by the General Assembly on 25 September 2015, transforming our world: the 2030 agenda for sustainable development, $\mathrm{A} / \mathrm{RES} / 70 / 1$

US Census Bureau, American Community Survey, 2015. water resource management. Land use policy, 75, pp.237-251.

Weitzer R (1996) Racial discrimination in the criminal justice system: Findings and problems in the literature. Journal of Criminal Justice, 24(4), pp.309-322.

Willis K (2016) International development planning and the sustainable development goals (SDGs). International Development Planning Review, 38(2), p.105.

World Bank (2020) Understanding poverty. Available at:

Yinger J (1986) Measuring racial discrimination with fair Housing audits: caught in the act. Am. Econ. Rev. 76:881-892. 